\title{
ARTIKELEN
}

PEER REVIEWED

\section{Knokkers en vrije jongens}

\section{Het criminele verleden van het Nederlandse kickboksen ${ }^{*}$}

\author{
Frank van Gemert
}

\section{Inleiding}

Mejiro en Chakuriki zijn twee Amsterdamse gyms die vaak in één adem worden genoemd, want ze speelden samen in de jaren zeventig en tachtig een prominente rol bij het begin van het Nederlandse kickboksen. Vechters uit deze gyms grossierden in successen en droegen bij aan de vooraanstaande positie die Nederland ging bekleden in de wereld van het kickboksen. Rond de eeuwwisseling zou dat culmineren in een reeks kampioenen bij het prestigieuze K-1-toernooi. Aan het vroege tijdperk zit echter een kwalijke reuk, onder andere vanwege ernstige geweldsincidenten. Daar wordt in de kickbokswereld weinig over gesproken, maar het is wel bekend. ${ }^{1}$ Deze geschiedenis is relevant, want kickboksen raakte verknoopt met criminaliteit en ook daarna deden zich nog incidenten voor. In dit artikel wordt dat begin met Mejiro en Chakuriki uitgeplozen; mogelijk dat ook de meer recente situatie zo beter kan worden begrepen.

Badr Hari zorgde voor ophef door zowel binnen als buiten de ring geweldsgrenzen te overschrijden, maar incidenten waren er al veel eerder en daarbij kwamen links met de onderwereld aan de oppervlakte. Meer dan twintig vechters, onder wie André Brilleman, Miloud El Guebli, Nordin Ben Salah, Tarik El Idrissi en Hans Nijman, kwamen op gewelddadige wijze om het leven. ${ }^{2}$ De toernooien ofwel de kickboksgala's hadden soms een schimmige organisatie en er werd samengewerkt met dubieuze sponsoren. ${ }^{3}$ De Amsterdamse burgemeester Van der Laan bestem-

* Dr. F.H.M. van Gemert is criminoloog en werkt bij de Vrije Universiteit in Amsterdam.

1 J. Olde Kalter, Kickbokser, Amsterdam: Prometeus 2011; J. Olde Kalter, Badr. De harde werkelijkheid achter Badr Hari, Amsterdam: Prometeus 2013; T. Harinck \& J. Punch, Thom Harinck; Godfather of muay thai kickboxing in the west, Amsterdam: Amsterdam Publishers 2016.

2 F. van Gemert, Straatkrediet; Biografie van Said Bensellam, Meppel: Just Publishers 2015, p. 57-62; L. Loef \& E. Lagendijk, Bad boys network. Over de relatie tussen full contact vechtsport en criminaliteit, Amsterdam: DSP-groep 2015, p. 10-13.

3 RIEC, Verwevenheid in de ring bij kickboksen, MMA, freefight en K1. Een onderzoek naar de aard en omvang van georganiseerde criminaliteit in relatie tot vechtsportevenementen in Noord-Holland, Regionaal Informatie en Expertise Centrum Noord-Holland 2012; M. Dortants \& M. van Bottenburg, Aanzien en overleven in een sport vol passie. Over regulering van full-contact vechtsporten, Nieuwegein: Arko Sports Media 2013; Werkgroep Handhaving, Rapport werkgroep handhaving martial arts ringcontactsporten, Amsterdam 2014. 
pelde de gala's als 'netwerkbijeenkomsten van de onderwereld' en in september 2010 verbood hij ze in de hoofdstad. Bij gala's in Hoorn en het Brabantse Zijtaart deden zich daarna nog ernstige geweldsincidenten voor waarbij werd geschoten en een dode viel.

Vooraanstaande vechters en trainers trokken aan de bel en stelden een manifest op waarin ze hun bezorgdheid uitdrukten. Ze bepleitten een reorganisatie van binnenuit. ${ }^{4}$ Er volgde onderzoek, een conferentie vond plaats en een discussie over regulering kwam op gang, want de wereld van full-contact vechtsporten is met negen verschillende bonden uitermate chaotisch. ${ }^{5} \mathrm{Na}$ Kamervragen werd een stuurgroep in het leven geroepen die onder voorzitterschap van burgemeester Van der Laan een plan van aanpak schreef. ${ }^{6}$ Ten aanzien van openbare orde werden nieuwe maatregelen geformuleerd, maar het lukte niet het Nederlandse kickboksen van binnenuit te reguleren en de discussie dreigde te verzanden. ${ }^{7}$ Een uitvloeisel van deze inspanningen is de Nederlandse Vechtsportautoriteit. Deze nieuwe toezichthouder, die bestaat sinds september 2017, positioneert zich tussen bonden, (vooral lokale) overheid en sporters. ${ }^{8}$ Tot de te ontwikkelen instrumenten behoren een digitaal wedstrijdboekje, een richtlijn voor de organisatie van full-contact vechtsportevenementen en een licentiesysteem voor promotors, trainers, coaches, juryleden, scheidsrechters en ringartsen.

Jan Plas (1945) was de oprichter van Mejiro gym. Tot zijn kampioenen behoren vechters als Rob Kaman, Luciën Carbin en Fred Royers. De naam van Thom Harinck (1943) is verbonden aan Chakuriki gym. Hij behaalde successen met onder anderen Peter Aerts, Branko Cikatic, Badr Hari en Hesdy Gerges. Jan Plas is dood, hij pleegde in 2010 zelfmoord in de gevangenis, waar hij een straf van acht jaar moest uitzitten. Thom Harinck stopte in 2013 als trainer, maar pikte de draad weer op, zij het dat hij niet meer een eigen gym heeft. Beide mannen speelden een cruciale rol bij de introductie van kickboksen in Nederland en ze waren ter plekke toen de sport een kwalijke ontwikkeling doormaakte.

Dit artikel doet verslag van een beschrijvend onderzoek en draait om de vraag: hoe raakte kickboksen in Nederland in de beginjaren verknoopt met criminaliteit? Om die vraag te beantwoorden kan men geneigd zijn om direct in te zoomen naar de twee gyms van het vroege uur, maar er is een breder kader nodig om te kunnen begrijpen wat zich heeft afgespeeld. Nadat in de volgende paragraaf wordt inge-

4 Volkskrant, 'De kickbokssport is een bedreiging voor de samenleving geworden', Volkskrant 26 november 2012, www.volkskrant.nl/sport/manifest-de-kickbokssport-is-een-bedreiging-voor-desamenleving-geworden a3353544/.

5 Werkgroep Handhaving 2014; G. Asscher, Vechtersbazen. Een cultureel-criminologische analyse van criminaliteit en full-contact vechtsporten (scriptie), Utrecht: Rijksuniversiteit Utrecht 2015; Dortants \& Van Bottenburg 2013; Loef \& Lagendijk 2015.

6 M. van Koolwijk, E. Lagendijk \& H. van Egdom, Eindrapportage regulering full contact vechtsporten: 'Regulering vechtsport is samenspel', NOC*NSF 2014.

7 Volkskrant, 'Kickboksen verloedert door geruzie', Volkskrant 17 februari 2015, www.volkskrant. nl/sport/pamflet-kickboksen-verloedert-door-geruzie a3853581/; M. Dortants, A. Knoppers \& M. van Bottenburg, 'Challenges in regulating full contact martial arts and combat sports', International journal of sport policy and politics 2016, DOI:10.1080/19406940.2016.1170717. www.vechtsportautoriteit.nl. 
gaan op de gebruikte methode, staan we stil bij bestaand onderzoek naar de link tussen criminaliteit en vechtsport en dan volgt een schets van ontwikkelingen van de vechtsport in de hoofdstad. Deze paragrafen bieden daarmee zowel een theoretisch kader als beschrijvingen van het proces van verknoping en van de context waarbinnen dat destijds gebeurde.

Deze specifieke kwestie van het criminele verleden van het kickboksen is onderdeel van een groter onderzoek. Andere aspecten van de complexe geschiedenis van het kickboksen in Nederland en de transformaties daarbinnen worden belicht in te verschijnen artikelen over (1) de ontwikkeling van kickboksen, ${ }^{9}$ (2) narratieven in de vechtsport, en (3) sociale stijging van Marokkaanse kickboksers. ${ }^{10}$

\section{Methode}

Dit artikel is gebaseerd op een kwalitatief onderzoek dat hoofdzakelijk in Amsterdam is uitgevoerd. Het omvat participerende observatie, interviews en bestudering van literatuur en van berichten in klassieke media en op internet.

Van april 2014 tot zomer 2018 heeft de onderzoeker wekelijks één of soms twee keer kickbokstrainingen gevolgd. De in totaal ongeveer 200 trainingen vonden plaats bij Van der Vathorst gym (67 keer) en na overname bij Bensy gym (ongeveer 120 keer) en bij acht andere gyms, waar één of twee keer werd meegetraind. De onderzoeker heeft twee keer bij Mejiro getraind en hij heeft twee trainingen van wedstrijdvechters bijgewoond onder leiding van Thom Harinck. Daarnaast is hij aanwezig geweest bij vijf kickboksgala's: twee keer een groot gala in Amsterdam van Glory (26 en 31), twee gala's in Almere en een gala in Driemond. Van al deze gebeurtenissen zijn uitgebreide fieldnotes gemaakt.

Het onderzoek ging van start met participerende observatie; de andere methoden zijn later gebruikt. Volgens een inductief patroon dienden zich vragen aan die opborrelden uit het verzamelde materiaal. Deze vragen werden gebruikt in 30 interviews met trainers, (gewezen) wedstrijdvechters en enkele recreatieve kickboksers. Voor dit artikel is in het bijzonder relevant dat Thom Harinck twee keer werd geïnterviewd en vier mannen die destijds bij Chakuriki trainden, elk één keer (respondenten $\mathrm{C} 1 \mathrm{t} / \mathrm{m} \mathrm{C} 4$ ). Er heeft een interview plaatsgevonden met André Mannaart, die Mejiro in 1990 overnam van Jan Plas, en met vijf mannen die in de beginjaren bij deze gym trainden, allen separaat (respondenten M1 t/m M5). Deze interviews zijn opgenomen en steeds een dag later uitgewerkt tot uitgebreide verslagen.

Wetenschappelijke literatuur over kickboksen in Nederland is dun gezaaid. Er is gepubliceerd over full-contact vechtsporten en 'ontsporting'. ${ }^{11}$ Meer recente

9 F. van Gemert, 'Kickboksen 2.0', in voorbereiding.

10 F. van Gemert, 'Kickboksen, een Marokkaanse route naar succes?', Sociologie 2019, 1.

11 M. van Bottenburg \& J. Heilbron, De verharding van het wedstrijdvechten, Amsterdam: Diopter 1996; M. van Bottenburg \& J. Heilbron, 'De-Sportization of Fighting Contests: The Origins and Dynamics of No Holds Barred Events and the Theory of Sportization', International Review for the Sociology of Sport 2006, 41, p. 259-282. 
publicaties hebben betrekking op de discussie rond regulering, ${ }^{12}$ soms in combinatie met vragen over verwevenheid met criminaliteit. ${ }^{13}$ Over bekende kickboksers is een reeks biografieën geschreven en een deel daarvan is voor dit artikel interessant omdat de hoofdpersonen trainden onder Thom Harinck, te weten Peter Aerts ${ }^{14}$ en Badr Hari. ${ }^{15}$ Ernesto Hoost ${ }^{16}$ werd tijdens wedstrijden gecoacht door Jan Plas, en Remy Bonjasky trainde bij Mejiro. ${ }^{17}$ De biografieën van Marloes Coenen, ${ }^{18}$ Joop Gottmers, Jan Oosterbaan, Lucia Rijker, ${ }^{19}$ Eddy Smulders ${ }^{20}$ en Rico Verhoeven ${ }^{21}$ zijn relevant, omdat daarin ook naar voren komt wat zich afspeelt in de wereld van vechtsport. Uiteraard zijn de biografie die verscheen over trainer Thom Harinck ${ }^{22}$ en een eerder boek dat hij schreef en in eigen beheer heeft uitgegeven over de Chakuriki vechtstijl ${ }^{23}$ ook van belang voor dit artikel.

In dag- en weekbladen zijn berichten verschenen die tot enkele jaren geleden in meerderheid betrekking hadden op de link tussen kickboksen en criminaliteit. De aanleiding was vrijwel steeds een negatief feit, successen bleven als regel onvermeld. ${ }^{24}$ Pas na 2015 is daar verandering in gekomen. Op de Nederlandse publieke televisie werd jarenlang heel weinig aandacht besteed aan kickboksen. Er waren korte items in nieuwsprogramma's ${ }^{25}$ en enkele documentaires over Chakuriki ${ }^{26}$ en over de misstappen van Badr Hari, ${ }^{27}$ en er was de dramaserie Vechtershart uit 2015 en 2017. Op de commerciële televisie werd in 1999 en 2000 (eerst SBS6 en later RTL5) in het programma Mylene knokt door gekeken naar de Nederlandse vechters bij de K-1-toernooien in Japan. Inmiddels zijn wedstrijden van vechtsporten vaak te zien en worden er ook realityprogramma's rond vechters ver-

M. Dortants, Power and Truths in Combat Sports; The impact of societal and policy changes on governing practices in sport (dissertatie), Utrecht 2017; Dortants \& Van Bottenburg 2013; Van Koolwijk, Lagendijk \& Van Egdom 2014.

13 Asscher 2015; Loef \& Lagendijk 2015; E. Lagendijk \& I. Deelen, Waard om te vechten. Over de waarde van full contact vechtsport voor jongeren, Amsterdam: DSP-groep 2018.

14 D. Dee \& K. ten Haaf, Peter Aerts; The Dutch lumberjack, Groningen: uitgeverij Passage 2014.

15 Olde Kalter 2013; M. Bax, Badr Hari, mijn verhaal, Utrecht: Kosmos Uitgevers 2014.

16 Olde Kalter 2011.

17 M. van den Dungen, Remy Bonjasky; God in Japan, Antwerpen: Houtekiet 2008.

18 M. Coenen, Kracht. Lessen, uit de kooi, Amsterdam: Bruna 2017.

19 T. Reitsma, Lucia million dollar babe. Biografie van een wereldkampioene boksen, Baarn: Tirion 2005; G. Schouten \& L. Rijker, Lucia Rijker. Bokser en boeddhist. Utrecht: Kosmos 2013.

20 W. Burgers, 'Fast' Eddy Smulders. Zijn onstuitbare opmars naar de wereldtop, Zutphen: Alpha 1997.

21 L. Verdonschot, Rico, Amsterdam: Voetbal Inside 2017.

22 Harinck \& Punch 2016.

23 T. Harinck, Chakuriki. De ontleende kracht, Amsterdam: Dojo Chakuriki 1980.

24 J. van Bon, Entering the world of martial arts; Different perspectives on full contact martial arts and crime in the Netherlands (scriptie), Utrecht: Utrecht University 2014; J.J.H. Dehue e.a., Opboksen en neerslaan. Een studie naar de link tussen kickboksen en criminaliteit (scriptie), Amsterdam: Vrije Universiteit 2015.

25 AVRO, AVRO's Sportpanorama, uitgezonden op 3 december 1977, www.youtube.com/watch?v= YIHQmoquvZ8.

26 VARA, Chakuriki, documentaire Vara Sport '80, uitgezonden op 2 januari 1981, www.youtube. com/watch?v=v1Ra8XWIAm4; IKON, Vechtershart, documentaire uitgezonden op 16 december 2006.

27 KRO, De storm van Badr Hari, documentaire in serie Profiel, uitgezonden op 27 juni 2011, www. documentairenet.nl/review/de-storm-van-badr-hari/. 
toond. Remy Bonjasky en Rico Verhoeven schuiven tegenwoordig met enige regelmaat aan bij talkshows of sportprogramma's.

Op internet is een veel grotere verzameling berichten en video's te vinden; vaak zijn die gekoppeld aan sites van een bond of gym. Vooral op YouTube staat een haast onuitputtelijke verzameling video's met gevechten of korte documentaires over vechters en gyms. Voor dit artikel is ook van die documentaires gebruikgemaakt. ${ }^{28}$

Chakuriki is goed gedocumenteerd, niet in de laatste plaats door inspanningen van Thom Harinck zelf. De oudere documenten (op schrift en in beeld) zijn waardevol omdat daarin is vastgelegd hoe deze trainer destijds onder woorden bracht wat hem drijft. Mejiro krijgt vanwege de successen van vechters ook ruim aandacht, maar Jan Plas heeft zich niet gepresenteerd zoals Harinck dat deed. Over hem werden geen boeken geschreven of documentaires gemaakt. Hij komt kort aan het woord in de biografie van Ernesto Hoost, ${ }^{29}$ en in het rijk geillustreerde boek Dutch Old School Kickboxing Icons wordt een bondig in memoriam aan hem gewijd. ${ }^{30}$ Zijn loopbaan is korter en heeft andere accenten.

Voor dit artikel, dat zoals gezegd onderdeel is van een reeks publicaties, wordt vooral gebruikgemaakt van interviews met personen die de twee gyms goed kennen. Deze data worden aangevuld met geschreven bronnen. De participerende observatie is hier van waarde, omdat zo contacten werden gelegd om toegang te krijgen tot de wereld van het kickboksen.

\section{Vechtsport en criminaliteit}

Bestaand onderzoek spitst zich veelal toe op de vraag of vechtsport een positieve dan wel negatieve invloed heeft op de ontwikkeling van (jeugdige) beoefenaars en behoort tot het terrein van sociale psychologie of pedagogiek. Gaat het om gedrag dat wordt geleerd door rolmodellen te volgen, ook als dat verkeerd en/of gewelddadig gedrag is? Worden in de sport masculiene codes overgedragen? Of biedt sport de mogelijkheid om stoom af te blazen en wordt onwenselijk gedrag juist voorkomen door ook discipline te trainen? Noors onderzoek wijst uit dat jonge vechtsporters in de sportschool in aanraking komen met een machocultuur en er agressieve gedragsrepertoires leren die ze ook elders toepassen. ${ }^{31}$ Soortgelijk zijn

O.a. VARA 1981; T. Harinck, Born To Fight, instructiefilm van Chakuriki, gemaakt in eigen beheer, 1994, www.youtube.com/watch?v=GgXeUPhvnho; AVAF, Rob Kaman, The legendary, documentaire, 2013a, www.youtube.com/watch? $\mathrm{v}=2$ H9uar5nCMA\#t=14.769979; AVAF, Thom Harinck, Decades of pride, documentaire, 2013b, www.youtube.com/watch?v=URg7VY95XPk.

29 Olde Kalter 2011, p. 112.

30 A. Coenen, J.-M. van Braak \& M. de Ruiter, Dutch Old School Kickboxing Icons, Rotterdam: Trichis Publishing 2010, p. 2.

31 I.M. Endresen \& D. Olweus, 'Participation in power sports and antisocial involvement in preadolescent and adolescent boys', Journal of Child Psychology and Psychiatry 2005, 2, p. 468-487. 
de bevindingen van Kreager, ${ }^{32}$ die vindt dat masculien, gewelddadig gedrag in de context van full-contact vechtsporten wordt aangemoedigd.

Verschillende reviewstudies werden uitgevoerd. Vertonghen en Theeboom, ${ }^{33}$ die in een kwalitatieve studie 27 onderzoeken bespreken, concluderen dat jongeren die lang aan vechtsporten doen minder agressief zijn. Gubbels e.a. ${ }^{34}$ vergelijken twaalf wetenschappelijke artikelen en kiezen daarbij een kwantitatieve insteek. $\mathrm{Zij}$ concluderen dat een relatie tussen vechtsport en crimineel of antisociaal gedrag niet wordt aangetoond. Onderzoek in diverse Europese landen laat zien dat vechtsporten kansen bieden aan kwetsbare jongeren. ${ }^{35}$ Elling en Wisse ${ }^{36}$ wijzen op contextuele factoren die een belangrijke rol kunnen spelen bij de relatie tussen criminaliteit en vechtsport. De invloed van peers en gatekeepers wordt genoemd, en daarnaast kan het pedagogisch klimaat agressief of crimineel gedrag voorkomen of juist aanwakkeren. ${ }^{37}$

Op straat worden masculiene waarden als fysieke kracht en mentale hardheid hoog aangeslagen ${ }^{38}$ en het is daarom geen toeval dat full-contact vechtsporten vanwege deze elementen voor bepaalde jongeren aantrekkelijk zijn. ${ }^{39}$ Het effect hoeft echter niet negatief te zijn. In Deens onderzoek blijkt dat ex-gangleden vechtsport op waarde schatten omdat ze er nieuwe narratieven in vinden die hun mannelijkheid niet ter discussie stellen. ${ }^{40}$ Wacquant ${ }^{41}$ bespreekt in een etnografisch onderzoek naar zwarte boksers in Chicago ook een verband tussen de gym

32 D.A. Kreager, 'Unnecessary Roughness? School Sports, Peer Networks, and Male Adolescent Violence', American Sociological Review 2007, 5, p. 705-724, https://doi.org/10.1177/ 000312240707200503.

33 J. Vertonghen \& M. Theeboom, 'The social-psychological outcomes of martial arts practice among youth: A review', Journal of Sports Science and Medicine 2010, 4, p. 528-537.

34 J. Gubbels e.a., 'Martial arts participation and externalizing behavior in juveniles: A meta-analytic review', Aggression and Violent Behavior 2016, 28, p. 73-81, http://doi.org/10.1016/j.avb.2016. 03.011.

35 M. Theeboom \& E. Verheyden, Vechtsporten met een +. Extra kansen voor kwetsbare jongeren, Brussel: Vrije Universiteit Brussel 2011.

36 A. Elling \& E. Wisse, Beloften van vechtsport, Nieuwegein: Arko Sports Media 2010.

37 N. Boonstra \& N. Hermens, De maatschappelijke waarde van sport. Een literatuurreview naar de inverdieneffecten van sport, Utrecht: Verwey Jonker Instituut 2011.

38 J. Gottschall, Echte mannen vechten. Hoe mannen de pikorde bepalen, Amsterdam: Maven Publishing 2015; J. Ilan, Understanding street culture; Poverty, crime, youth and cool, Londen: Palgrave MacMillan 2015; J.D. de Jong, Kapot moeilijk. Een etnografisch onderzoek naar opvallend delinquent groepsgedrag van 'Marokkaanse' jongens, Amsterdam: Aksant 2007; C.W. Mullins, Holding your square; Masculinities, streetlife and violence, Collumpton: Willan 2006; R. Roks, In de H200d. Een eigentijdse etnografie over de inbedding van criminaliteit en identiteit, Rotterdam: Erasmus Universiteit Rotterdam 2016.

39 Loef \& Lagendijk 2015; Lagendijk \& Delen 2018.

40 R. Deuchar e.a., 'When you're boxing you don't think so much; Pugilism, Transitional Masculinities and Criminal Desistance among Young Danish Gang Members', Journal of Youth Studies 2015, 8, p. 1-18; T.F. Søgaard e.a., 'Desistance and the micro-narrative construction of reformed masculinities in a Danish rehabilitation centre', Criminology \& Criminal Justice 2015, 1, p. 99-118.

41 L. Wacquant, 'Pugs at Work: Bodily Capital and Bodily Labour among Professional Boxers', Body \& Society 1995, 1, p. 65-93; L. Wacquant, Body \& Soul; Notebooks of an Apprentice Boxer, New York: Oxford University Press 2004. 
en criminaliteit. Hij stelt vast dat het juist de disciplineerde vechters zijn die afstand weten te bewaren tot drugs en geweld van het getto.

Een eenduidig antwoord over de relatie tussen vechtsport en criminaliteit wordt in deze literatuur niet gegeven. Enerzijds is evident dat geoefende vechters effectief geweld kunnen gebruiken, wat hen in een criminele loopbaan van pas kan komen. Anderzijds kennen ze de risico's van vechttechnieken en wordt er in de gyms op gehamerd die niet verkeerd toe te passen. De meeste studies wijzen in de richting van een positieve invloed van vechtsport, die antisociaal of crimineel gedrag eerder remt dan aanwakkert.

In de criminologie bestaat sinds jaar en dag aandacht voor het leren van crimineel gedrag $^{42}$ en daarin komen een paar algemene vragen steeds weer aan de orde: wie zijn de rolmodellen en wat wordt er geleerd? Wat er binnen de muren van de gym wordt overgedragen, kan veel invloed hebben, omdat bij vechtsport de trainer een bijzondere positie en rol heeft. ${ }^{43} \mathrm{Om}$ te kunnen begrijpen hoe er in Nederland in de vroege jaren een link tot stand kwam tussen kickboksen en criminaliteit is dit perspectief van leren echter niet toereikend, want de focus op wat er gebeurt in de gym is te beperkt. Er zijn belangrijke activiteiten die simpelweg niet op deze locatie plaatsvinden en daarnaast is ook de historisch-sociologische context relevant om te kunnen begrijpen wat er destijds gebeurde en welke betekenis dat heeft.

Onder 'verknoping van kickboksen met criminaliteit' wordt het proces verstaan waarbij kickboksers betrokken raakten bij criminele activiteiten. Dit artikel biedt niet een analyse van delicten van kickboksers. Het proces wordt beschreven aan de hand van drie vragen die zich logischerwijs aandienen. Wie zijn deze vechtsporters? Waar komen ze in aanraking met kringen met criminele activiteiten? Waarom gaan ze mee in wat daar gebeurt? Dit speelt zich af binnen een specifieke setting van Amsterdam in de jaren zeventig en tachtig. In de volgende paragraaf komt die nationale context als eerste ter sprake; een meer uitvoerige bespreking van internationale ontwikkelingen komt aan bod in een separate publicatie. ${ }^{44}$

\section{Nieuwe vechtstijlen in Nederland}

Na de Tweede Wereldoorlog vormen voorheen onbekende oosterse vechtsporten een nieuw fenomeen in het Westen. Via de klassieke media en door middel van films raken ze bekend, maar er zijn ook demonstraties. Onder vechters rijst de vraag welke stijl het meest effectief is, en in het verlengde daarvan vinden op

42 O.a. A. Bandura, Social foundations of thought and action: A social cognitive theory, Englewood Cliffs: Prentice Hall 1986; R.L. Burgess \& R.L. Akers, 'A Differential Association-Reinforcement Theory of Criminal Behavior', Social Problems 1966, 2, p. 128-147; E.H. Sutherland, Principles of Criminology, Chicago: University of Chicago Press 1924.

43 Asscher 2015; Loef \& Lagendijk 2015; Lagendijk \& Deelen 2018; Van Gemert, in voorbereiding; Van Gemert 2019.

44 Van Gemert, in voorbereiding. 
diverse plekken en in allerlei vormen gevechten plaats. ${ }^{45}$ Vechters leren en lenen van elkaar en zo ontstaan nieuwe vechtstijlen, waarvan kickboksen er één is. ${ }^{46}$ In 1964 worden de Olympische Spelen in Tokio gehouden en in het hol van de leeuw wordt Anton Geesink de eerste olympische kampioen judo in de open klasse. Dit geeft de sport judo in Nederland een krachtige impuls. Karate is in Nederland als sport de belangrijkste voorloper van kickboksen. De harde variant van kyokushinkai karate wordt sinds 1962 in Amsterdam getraind onder leiding van karateka Jon Bluming. Hij trainde zelf in Japan onder de legendarische Oyama en was de eerste buitenlander die daar les mocht geven in karate.

Op diverse continenten ontstaan nieuwe organisaties, die allemaal hun eigen regels hebben, met elk hun eigen (wereld)kampioenen. ${ }^{47}$ Omdat een aantal van deze bonden klein is en beperkte mogelijkheden heeft voor interne competitie, groeit de behoefte zich te meten met vechters van andere bonden en zo ontstaan gemengde competities. Wedstrijden worden georganiseerd door een bond, maar vechters van andere bonden kunnen ook deelnemen, mits ze zich houden aan vooraf overeengekomen regels.

De aandacht voor specifieke vechtstijlen is mede afhankelijk van persoonlijke voorkeuren en kent nogal wat variatie. Zo raakt in Rotterdamse sportscholen als Maeng Ho en Baek Ho onder trainers Martin Borneman en Joop Musterd American kickboxing in zwang, dat ook wel 'full-contact' wordt genoemd. ${ }^{48}$ Het verschil met kickboksen is dat hier knieën en low kicks niet zijn toegestaan.

Thom Harinck is een Amsterdammer die zich in karate bekwaamt, hij krijgt les van Jan Stapper. De leermeester ziet wel wat in Harinck, die hij al vroeg in een team stopt met zwarte band karateka's, hoewel Harinck dat niveau formeel nog niet heeft. Harinck kan goed vechten en in een wedstrijd slaat hij zijn tegenstander met de hand knock-out, een ongeoorloofde techniek. Diskwalificatie volgt en dat is voor de teleurgestelde Harinck het moment om een knoop door te hakken en zich te gaan toeleggen op een eigen karatestijl. ${ }^{49} \mathrm{Hij}$ opent in 1972 een school die hij 'Chakuriki' noemt, wat zoveel betekent als 'ontleende kracht', en daar traint hij zijn eigen vechters. Hij krijgt bezoek van een karateka die hem namens Jon Bluming komt vertellen dat hij illegaal de zwarte band draagt. Harinck antwoordt dat het geen zwarte band kyokushinkai is, maar Chakuriki, zijn eigen stijl. Hij weigert de band af te doen en trakteert de boodschapper op een linkse hoek. Dit nieuws verspreidt zich onmiddellijk en het symboliseert, met inhoud en vorm, Harincks breuk met de gevestigde orde van het Nederlandse karate. ${ }^{50}$

In 1975 gaan drie andere Amsterdamse karateka's naar Japan om te trainen. Jan Plas, Peter van den Hemel en politieman Jan van Looijen bezoeken in Tokio hun eerste kickbokswedstrijden in een groot honkbalstadion en dat is voor hen een ongekend spektakel. Zij gaan op onderzoek uit en komen terecht bij een gym in de

45 Asscher 2015; Bottenburg \& Heilbron 1996, 2006.

46 W. Brunekreef, The golden Kyokushin and K-1 encyclopedia, Knoxville: MAproductions 2007.

47 Brunekreef 2007, p. 228.

48 K. Scharrenberg, Jantje O. Het veelbewogen leven van vechtsportlegende Jan Oosterbaan, Meppel: Just Publisers 2018.

49 Harinck \& Punch 2016, p. 10; www.youtube.com/watch?v=aDoY-4R_gcE.

50 Harinck \& Punch 2016, p. 16. 
wijk Mejiro. De drie mogen deelnemen aan trainingen en worden geconfronteerd met een harde aanpak en met technieken die hun onbekend zijn, zoals de low kick. Met veel inspiratie keren de mannen weken later weer terug naar Nederland. ${ }^{51}$ Jan Plas gaat lesgeven in het nieuwe kickboksen en in 1978 opent hij Mejiro, de gym die hij vernoemt naar de wijk in Tokio.

Op 31 mei 1976 worden voor het eerst in Nederland kickbokswedstrijden georganiseerd. In de Jaap Edenhal staan de vechters van Chakuriki en die van Mejiro in keiharde wedstrijden tegenover elkaar. Er komt veel publiek op af en er wordt in de stad veel over gepraat. ${ }^{52}$ Jan Plas en Thom Harinck slaan hiervoor de handen ineen en kickboksen in Nederland krijgt een grote impuls. De twee pioniers zijn vanaf dat begin zowel elkaars gedoodverfde concurrenten als compagnons en hun paden kruisen elkaar veelvuldig.

\section{Wie?}

De gym van Thom Harinck is gevestigd in de Staatsliedenbuurt, maar hij moet diverse keren verhuizen en om hulp vragen bij de wethouder voor Chakuriki terechtkomt in een voormalige school voor schipperskinderen in de Van Hallstraat. In de jaren negentig gaat Harinck zich toeleggen op het trainen van de wedstrijdvechters uit zijn gym, en zijn voormalige rechterhand neemt de leiding over. Harinck zoekt een andere locatie en in 2002 verhuist hij naar de Zilverberg in Noord en begint samen met Chris Dolman de gym Pancration.

Jan Plas geeft aanvankelijk les in kickboksen in een boksschool aan het Singel en later in de dojo van zijn karateleermeester Jon Bluming aan de Valkenburgerstraat. In 1978 opent hij Mejiro, de gym die vandaag de dag nog steeds gevestigd is aan de Lauriergracht in de Jordaan. In 1990 doet Jan Plas Mejiro over aan zijn leerling André Mannaart. Hij is zelf met andere zaken bezig, maar hij komt wel over uit het buitenland om Rob Kaman te trainen voor specifieke wedstrijden. Hij treedt later ook nog op als coach bij wedstrijden van Ernesto Hoost en dat doet hij in dienst van de gym van Johan Vos. ${ }^{53}$

Amsterdam kent in de jaren zeventig jeugdgroepen die met elkaar op de vuist gaan. Zo hebben de jongens uit de Jordaan en de Kinkerbuurt een enorme hekel aan elkaar. Deze jongeren vinden hun weg naar de gyms. 'Voor jongens van de straat die het leuk vinden om te vechten, was het heel aantrekkelijk, die nieuwe vechtsport. Wat ze kenden was niet hard genoeg, ze wilde grenzen verleggen. Te veel regels, dit mag niet, dat niet. Deze jongens houden niet van dat "tikken, tikken en weer weg”. Ze willen knokken' (interview respondent M5). Rob Kaman, destijds een zeer bekende vechter, over de rivaliteit tussen de vechters van Mejiro en Chakuriki: 'Het waren jonge jongens die wat kwijt moesten. Jonge haantjes, die zich willen bewijzen.' 54 'Wij vochten altijd op straat. Als jij bijdehand was, dan kon je klappen krijgen. Je wilt vechten en daar ga je iets mee doen. Kyokushin 
karate was ook heel hard en bruut, maar het was toch ook zen. Kickboksen daar hing een andere sfeer omheen. Dat had meer een westers imago. $\mathrm{Nu}$ was er een nieuwe manier om te vechten zonder in de problemen te komen' (interview respondent M3). 'Je hoorde over kickboksen, het maakte je nieuwsgierig. We zagen de posters van de wedstrijden in de stad. Harder, zeiden ze. Kijk, Bruce Lee, dat was mooi, maar dat was film, geen echt vechten. Dit was echt vechten' (interview respondent $\mathrm{C} 1$ ).

Bij Chakuriki trainen in het begin nogal wat jongeren met een migratieachtergrond, naar Mejiro komen vooral Nederlandse jongeren. 'Van begin af aan staan er bij wedstrijden straatjongens in de ring en het publiek paste daarbij. Er zaten geen hockeyers in de zaal, geen volleyballers. Het was gewoon een publiek van een lage sociale klasse' (interview respondent C3).

Veel grote namen van het 'old school Nederlands kickboksen' laten er geen misverstand over bestaan dat zij dezelfde achtergrond hebben. Ook zij waren jongens die van vechten hielden. ${ }^{55}$ Rotterdammer Jan Oosterbaan zegt: 'Ik ben een jongen van de straat. Buiten vocht ik alleen maar. ${ }^{56}$ Toch zijn het niet alleen knokkers die naar de gyms komen. Een kampioen karate raakt ook in de ban. 'Ik ging naar een gala en wist niet wat ik zag. Het was zo anders, zo hard. Zo hard. Ik dacht: dat kan ik niet. Maar ik moest het toch proberen. (...) Het was mij als karateka expliciet verboden door de bondscoach om me bezig te houden met kickboksen. Dat was gajes. Kickboksen was absoluut niet salonfähig, zoals het nu is. Men wilde niet geassocieerd worden met dat gespuis van het kickboksen' (interview respondent M1). Hij gaat trainen bij Mejiro onder Jan Plas en wordt ook kampioen in kickboksen.

Of de twee trainers ook van jongs af vechtersbazen waren, is niet bekend. Wel is duidelijk dat ze alle twee een verleden hebben met misstappen, maar het verschil tussen beiden is groot. Harinck wordt veroordeeld voor een valse belastingaangifte. 'Ik was een bengeltje, een sensatiebak, een makkelijke gozer. ${ }^{57} \mathrm{Na}$ een hoogoplopende ruzie in het nachtleven wordt tegen hem aangifte gedaan en hij moet twee dagen in een politiecel doorbrengen voor hij wordt heengezonden. Zijn slachtoffer blijkt een grote crimineel die 3000 gulden uitlooft voor degene die hem te grazen neemt, maar Harinck gaat zelf verhaal halen. 'Ik was toen ook wel een wilde jongen hoor. Die man schrok natuurlijk en toen heb ik zijn bierpomp er nog uit getrokken. Ik ben wel alleen gegaan hè' (interview Harinck). Verhaal halen doet hij jaren later nog eens wanneer zijn vrouw Marjan Olfers door een hooligan via e-mail wordt bedreigd vanwege haar werk als lid van de raad van commissarissen van Ajax. ${ }^{58}$ In een vliegtuig slaat hij een lastige passagier neer en oogst daarmee waardering van de bemanning. ${ }^{59}$ Zijn reputatie en vechttechnieken gebruikt Harinck dus nog steeds, mits dat naar zijn eigen maatstaven een goed doel dient. 'Vermijd het gevecht, probeer het te ontwijken, desnoods loop je weg. 
Maar word je gedwongen, lever dan een goed stuk werk' (interview Thom Harinck). ${ }^{60}$ Zijn vrouw heeft van hem een keurige burger gemaakt, zegt hij zelf. ${ }^{61}$ De loopbaan van Jan Plas is van een ander kaliber, met zware criminaliteit. Het duurt echter lang voor hij de consequenties van zijn misstappen moet ondergaan. Begin jaren tachtig laat Plas zich door Bertus Lüske inhuren als leider van een knokploeg die met het nodige geweld kraakpanden ontruimt. ${ }^{62}$ Het ligt voor de hand dat hij Mejiro-vechters hiervoor meeneemt. In 1985 is Jan Plas betrokken bij de ontvoering van de zoon van hasjhandelaar Gijs van Dam, maar hij ontspringt de dans als hij op vormfouten wordt vrijgesproken. ${ }^{63}$ Plas is in 1990 in dienst van Johan Verhoek, alias 'de Hakkelaar', voor wie hij in Canada geld administreert en beheert. ${ }^{64}$ Als kroongetuige in het proces tegen de Hakkelaar ontloopt hij weer zijn straf. In 2010 valt het doek en wordt Jan Plas veroordeeld tot een gevangenisstraf van acht jaar voor het leidinggeven en deelnemen aan een criminele organisatie die zich bezighoudt met grootschalige internationale drugshandel. ${ }^{65}$ In detentie pleegt Jan Plas zelfmoord.

\section{Waar?}

De knokkers komen op twee plaatsen in aanraking met kringen met criminele activiteiten, in de gym en in de cafés en clubs van het uitgaansleven. In de gym treffen ze anderen met wie ze normaal gesproken misschien niet in contact zouden komen. Mejiro had in de vroege jaren een merkwaardige mix van sporters. 'Jan van Looijen werkte bij de politie, dat was een goede bekende van Plas. Die kwam met een stuk of tien politiemannen en wij mochten met ze trainen. Dat was een droom. Wij waren straatjongens, wij gingen ze wat leren en we waren heel serieus. Maar aan het eind van de les gingen we sparren en dan wilde je toch een paar tikken uitdelen. Toen het klaar was bedankten ze ons. Het was leuk, maar ook zwaar, zeiden ze dan. Wij mochten politieagenten slaan, dat mocht gewoon legaal...' (interview respondent M2). Bij Mejiro kwam niet alleen politie binnen, maar ook de zware onderwereld. 'Ik mocht bij Mejiro op dinsdag en donderdag karateles geven, dat had Jan Plas voor me geregeld. Ik trainde daar kickboksen en ik mocht dus zelf ook les geven. Toen kwam Klaas Bruinsma op een keer binnen. Hij was heel erg in Japan geïnteresseerd, hij gebruikte ook Japanse woorden. "Sayonara", dat was geloof ik zijn favoriete uitdrukking. Hij vroeg of hij privé les kon krijgen. "Nou, dat doe ik niet, daar hou ik helemaal niet van. Dat is

60 Cf. Harinck \& Punch 2016, p. 20.

61 W. Meyer, 'Bij kickboksen heten het criminelen, in een Ajax-vipbox toeschouwers', Vrij Nederland 24 augustus 2015, www.vn.nl/marjan-olfers-en-thom-harinck-over-sport-en-misdaad/.

62 B. Middelburg \& P. Vugts, De oorlog in de Amsterdamse onderwereld, Amsterdam: Nieuw Amsterdam 2006; Middelburg \& Vugts 2006, p. 145.

63 Reformatorisch Dagblad, 'Vijf jaar voor ontvoerders Gijs van Dam', Reformatorisch Dagblad 13 maart 1986; Middelburg \& Vugts 2006, p. 145-146.

64 Olde Kalter 2011, p. 112.

65 B. Middelburg, 'Kickbokslegende toch KO?', Het Parool 26 maart 2010, https://www.parool.nl/ amsterdam/kickbokslegende-toch-ko a286029/; vonnis te vinden op http://deeplink. rechtspraak.nl/uitspraak?id=ECLI:NL:RBHAA:2010:BN0960. 
het saaiste wat er is, ik geef liever aan een groep les." Dat heb ik hem eerlijk gezegd. "Nou ja, in ieder geval bedankt", zei hij en toen frommelde hij me een briefje van honderd gulden in mijn hand. "Nee, nee", zei ik, "dat hoeft niet." Naderhand hoorde ik pas wie hij was. Ik dacht toen dat is gewoon een of andere patser. Eigenlijk hoorde ik pas wie hij was nadat hij dood was' (interview respondent M4).

Een deel van de vechters die bij Mejiro trainen, heeft criminele bezigheden, en de verhalen over André Brilleman en Miloud el Geubli laten zien dat het geen kruimelwerk is. Beiden verdwijnen, respectievelijk in 1985 en 1992. Brilleman is bodyguard van Klaas Bruinsma. Hij wordt geliquideerd en in een vat beton in de Waal gegooid. ${ }^{66}$ El Geubli is nooit teruggevonden. ${ }^{67}$ Binnen de muren van Mejiro is bekend dat sommigen zich met duistere zaken bezighouden, maar dat heeft geen consequenties. 'Vergeet niet dat in de gym een hele goede sfeer heerste. Plas werd gezien als een vader of een halfgod. Er werd hard getraind en onderling werden harde klappen uitgedeeld, maar er was respect. Iedereen was binnen heel aardig voor elkaar. We wisten dat Brilleman met dingetjes bezig was, maar hij was heel aardig. El Geubli verdween, is vermoedelijk vermoord, maar werd nooit gevonden. Dat heb ik nooit begrepen, het was een hele aardige jongen' (interview respondent M3). De sfeer lijdt niet onder hun aanwezigheid. Het effect is eerder omgekeerd: dit blijken juist hele aardige jongens en goede trainingsmaten te zijn. 'André Brilleman reed met mij mee naar huis na trainen en dan gingen we samen stappen. (...) Maar ik nooit bij hem' (interview respondent M1).

Thom Harinck weet dat hij veel knokkers van de straat in zijn gym heeft en hij realiseert zich dat een deel van hen zal afglijden. 'Ik ben al dertig jaar met jongeren bezig. Van sommige verwacht je het niet en dan gebeurt het toch. Het is dus eigenlijk een fifty-fifty kans.' 68 'Ik trainde bij Thom Harinck, maar het werd niets met dat vechten van mij, want ik zat steeds vast' (interview respondent C4). Harinck wil jongeren niet de deur wijzen, want hij herkent soms goede vechters en meent bovendien dat de vechtsport hen juist op het rechte pad kan houden. 'Er zijn veel foute mensen en die komen bij de Albert Heijn binnen en ze komen ook in mijn gym. Maar ik ben geen politieman. Wat je buiten doet is niet mijn zaak, maar hier binnen hou je je aan mijn regels.' ${ }^{69}$

De tweede plaats waar de vechtsporters in aanraking komen met kringen met criminele activiteiten is in de cafés en clubs, waar ook de hoofdstedelijke penoze te vinden is. Harinck en Plas hebben vanaf het begin veel contacten in deze kringen. Sterke mannen trainen vanaf 1973 in Sport Club Oyama onder leiding van Jan Stapper op de zolder van Casa Rosso aan de Oudezijds Achterburgwal, het kloppend hart van het imperium van Maurits de Vries, alias 'Zwarte Joop'. Zo kunnen kampioenen als judoka Wim Ruska en worstelaar Chris Dolman hun sportieve loopbaan combineren met hun werk als portier. De banden tussen vechtsport en het leven, Meppel: Just Publishers 2010, p. 222-227.

67 Idem, p. 228-237.

68 IKON 2006.

69 IKON 2006. 
penoze worden zichtbaar als Dolman zijn actieve vechtsportcarrière in 1995 beëindigt met een afscheidsgala en de prijzen worden uitgereikt door de later geliquideerde vastgoedmagnaat Bertus Lüske, Theo Heuft, die op dat moment eigenaar is van bordeel Yab Yum, en 'Big Willem' van Boxtel, destijds president van de Hells Angels. ${ }^{70}$

Als Jan Stapper in 1988 stopt, gaat Thom Harinck samenwerken met Dolman en Ruska. Ze betrekken de zolder en hernoemen de sportschool 'Doharu' (DOlman HArinck RUska). Harinck gaat de kickboklessen verzorgen. Zijn vechters van de Van Hallstraat trainen vanaf dat moment op de Wallen. Zwarte Joop legt hen in de watten en maakt gebruik van de gelegenheid om onder hen geschikt personeel te rekruteren voor de bewaking van zijn panden. ${ }^{71}$ Het duurt maar een jaar en dit lijkt een korte episode in de loopbaan van Harinck, maar zijn band met de horeca en het milieu op de Wallen duurt langer en is niet slechts oppervlakkig. ${ }^{72}$

Omdat het geven van vechtsporttraining in de beginjaren nog niet veel oplevert, werkt Harinck in de avonduren als portier. Hij heeft dat twaalf jaar gedaan, onder andere op het Leidseplein en het Thorbeckeplein en op de Botermarkt in Haarlem. ${ }^{73}$ Hij krijgt er een goed salaris en schakelt ook vechters van zijn school in. Die kunnen er ook wat verdienen, maar het draagt tevens bij aan de veiligheid. 'Ik werd gevraagd voor een hele moeilijke deur in Haarlem. Ik nam altijd vijf of tien leerlingen mee. Die vonden dat fantastisch om daar met mij naar toe te gaan, om de leraar te helpen. Ze konden goed vechten, dus ik had altijd rugdekking' (interview Harinck).

Ook Mejiro is in het begin geen stabiele bron van inkomsten en om die reden staat Jan Plas als portier aan de deur bij hotel Torenzicht op de Wallen. Hij werkt daar voor Aurore Robert, een mooie Indische vrouw die zelf in het verleden op de Gelderse kade haar geld verdiende en daar diverse panden kocht. Saillant is dat zij eind jaren zeventig een relatie heeft met Thom Harinck. ${ }^{74}$ Bij Torenzicht komt in die tijd een tamelijk ruw publiek, mensen die te veel hebben gedronken, motorrijders, Engelse toeristen, mariniers. De portier moet regelmatig optreden, maar Plas lijkt dat niet te deren. Eerder geniet hij van de mogelijkheid om zijn vechtkunsten te etaleren en hij vertelt daar graag over in de gym.

Middelburg \& Vugts 2006, p. 149.

\section{Harinck \& Punch 2016, p. 69.}

De eerste minuten van een in opdracht van Harinck gemaakte instructiefilm tonen hem als iemand die past in het milieu van de Wallen. Harinck is te zien als hij met zonnebril op, in een double-breasted pak met brede revers en een attachékoffertje in de hand, uit een luxe Mercedes stapt, nadat hij rijdend belde met een mobiele telefoon (in die tijd geen gemeengoed) en zijn dure horloge en pinkring opzichtig in beeld werden gebracht; www.youtube.com/watch?v= GgXeUPhvnho (Harinck 1994).

Harinck \& Punch 2016, p. 13.

Harinck \& Punch 2016, p. 44. 
Figuur 1 Rob Kaman, Peter van Os, Miloud El Geubli, André Brilleman, Fred Royers, Muzaffer Yamali

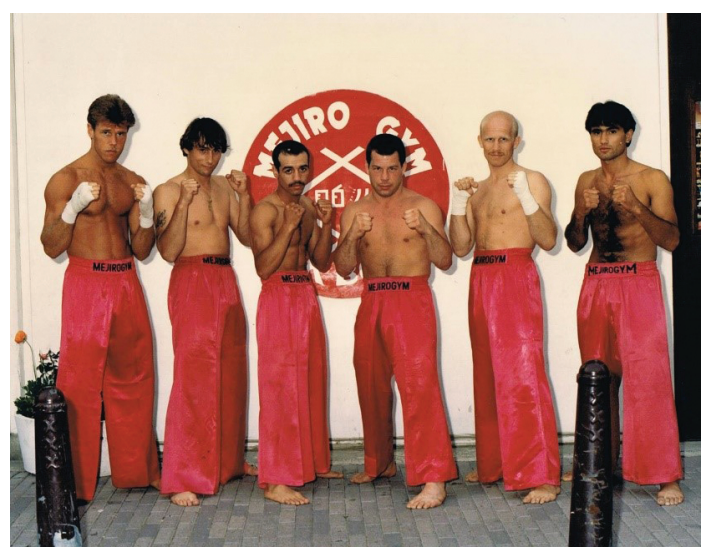

\section{Waarom?}

Vechters komen in de gym en in het uitgaansleven in aanraking met kringen met criminele activiteiten. Om verschillende redenen gaan sommigen mee in wat daar gebeurt. In de eerste plaats krijgen ze in de gym te maken met een heldere hiërarchie en strikte regels. Het is een setting die vooral bij Chakuriki sektarische trekjes vertoont. ${ }^{75}$ Eigenzinnige solisten gedijen daar niet.

Er kan geen twijfel over bestaan dat Plas en Harinck leiders zijn, die aimabel maar ook zeer dominant kunnen zijn. 'Bij Mejiro Gym was het altijd gezellig. Jan Plas was van het geintjes maken, maar vooral ook een charismatische leuke man' (interview respondent M2). Zijn autoriteit kan men niet over het hoofd zien. 'Er was een discipline die uitermate strikt was. Groeten voor en na de training, maar belangrijker nog: ik heb het in al die jaren nog nooit zien ontaarden in een ordinaire vechtpartij. Hard, heel hard. Maar als die ander zei stop, dan was het stop. En niemand zei tegen de sensei “Ja, maar..." Dan kon je oprotten of kreeg je een pak op je lazerij. Dat kwam echt niet in je op' (interview respondent M1). Er wordt serieus en hard getraind en er wordt in heldere taal gecommuniceerd. 'Van een jongen was een gouden kettinkje verdwenen. Hij meldde dat bij Jan Plas en die kwam briesend in de kleedkamer staan. "Als ik erachter kom wie dat ding heeft gepikt, dan schiet ik hem eigenhandig door zijn knieën"' (interview respondent M3).

De individuele vechter wordt ondergedompeld en meegevoerd in de dagelijkse gang van zaken binnen de muren van de gym. Discipline is vanzelfsprekend en dwarsliggen wordt niet gewaardeerd, maar daaraan bestaat ook weinig behoefte. 'Ik heb een leuke tijd gehad. Het waren boefjes en criminelen, maar het was heel leuk. Als fout slecht voelt, dan kun je makkelijk nee zeggen, maar als fout goed voelt, zeg dan maar eens nee' (interview respondent M1). 'Ik wist niet wat er alle- 
maal gebeurde. Je voelt wel wat of je hoort wel wat, maar ik wist het niet. Ze vroegen mij ook niet. Ik wilde niet de moraalridder zijn, die positie had ik niet en die wilde ik ook niet. Het zal wel zo zijn, maar ik kwam om te trainen' (interview respondent M4). 'Ik sprak ook wel eens met André Brilleman af in de Buggy, de coffeeshop aan de Bilderdijkkade. Daar boven zat het hoofdkwartier van de clan van Bruinsma, maar dat wist ik helemaal niet. Het was gewoon dicht bij de dojo en dan dronken we daar een kopje koffie voor of na de training. Ik rookte niet, André ook niet, dus daar ging het niet om. Ze hadden er altijd goede nieuwe muziek, dat was wel een goede reden om er heen te gaan' (interview respondent M3). Sommigen wisten meer, maar maakten geen bezwaar. "Ik moet even wat wegbrengen, kun je even meelopen?” Dat werd gevraagd bij Mejiro. "Loop jij maar even mee. Jij bent student, jij kunt het geld wel gebruiken”, dat zei Jan Plas tegen me' (interview respondent $\mathrm{M} 5$ ).

In de tweede plaats gaan de vechters mee in wat er gebeurt omdat er wat te verdienen is. In Amsterdam zal de belangstelling voor het kickboksen gaan groeien, maar in het begin is het geen vetpot. Ook de wedstrijden in het buitenland vertonen geen spoor van de glamour die later komt. 'Jan Plas had een oude Citroën. Hij reed zelf naar Parijs, de jongen die moest vechten lag achterin en dezelfde avond reed hij weer terug' (interview respondent M5). De economische crisis van de jaren tachtig brengt vooral onder jongeren veel werkloosheid, en veel vechters hebben geen werk. Tegelijkertijd kampt Amsterdam met drugsproblematiek. Het aantal coffeeshops groeit snel en de Zeedijk is een no-goarea. Amsterdamse penoze, Zwarte Joop voorop, ziet dit als een bedreiging voor de inkomsten uit de bordelen en gokhuizen op de Wallen. Wanneer dat nodig wordt geacht, vegen sterke mannen het uitgaansgebied schoon en junks belanden in de gracht. De vechters zijn ideale krachten om de kleine criminaliteit en straathandel van de drugsscene op afstand te houden. ${ }^{76}$ 'Een beetje geweld voor een goed doel' (interview respondent C2). 'Wanneer word je portier? Niet als je kunt pingpongen of biljarten. Je moet wel in staat zijn je te roeren. Je verwacht wel dat er een jongen staat die van wanten weet' (interview Harinck).

Voor vechtsporters is het werken als portier een bezigheid die zich goed laat combineren met hun dagelijkse trainingen. Harinck en Plas zijn zeker niet de enigen die aan de deur hebben gestaan; in hun kielzog krijgen veel vechters werk als portier bij cafés en clubs in de hoofdstad en daarbuiten. Ook André Mannaart, ${ }^{77}$ Jan Oosterbaan, ${ }^{78}$ Joop Gottmers, ${ }^{79}$ Peter Aerts en Dick Vrij, ${ }^{80}$ Rick van de Vathorst ${ }^{81}$ en vele anderen zijn portier geweest. 'Het was een droombaan. Ik mocht zo veel vechten als ik wilde en zou er nog voor betaald krijgen ook. Beter kon niet. Elk city of Amsterdam', in: I. Haen-Marshal \& Ed. Leuw (red.), Between prohibition and legalisation; The Dutch experiment in drug policy, Leiden: Kugler 1994, p. 145-168; B. Middelburg, De Mafia in Amsterdam, Amsterdam: de Arbeiderspers 1988. 
weekend kon ik met de grootste vechtersbazen op de vuist en iedereen was blij wanneer ik won. Ik werd overladen met complimenten, kreeg volop aandacht van de vrouwen en had al snel een geduchte reputatie. ${ }^{82}$

Dit is stressvol werk omdat er onherroepelijk geweld bij komt kijken. De onderlinge concurrentie kan hoog oplopen, want er is veel geld mee gemoeid en sterke mannen willen 'deuren nemen'. In Amsterdam woedt enige tijd een 'portiersoorlog'. 'Er stonden soms types aan de deur, bodybuilders, fitnesstypes, jongens die niks konden. Tja, die kun je wegpesten' (interview respondent C2). Mede vanwege de verkoop van drugs bekleden portiers een strategische positie aan de rand van de onderwereld. In de jaren negentig worden van overheidswege strengere richtlijnen opgelegd. Portiers worden sindsdien gescreend, ze moeten over een diploma beschikken en mogen geen strafblad hebben. ${ }^{83}$

In de derde plaats gaan vechters mee in wat er gebeurt in deze kringen omdat ze er waardering krijgen. In de reguliere media komt de nieuwe sport in het begin niet aan bod, en het harde full-contact gevecht vindt beslist geen aansluiting met de mainstream (zie voetnoot 9). In het Amsterdamse nachtleven daarentegen bestaat veel belangstelling, en kickbokswedstrijden worden op de voet gevolgd, met als gevolg dat kampioenen in de cafés en clubs worden herkend en benaderd.

Personen van wie bekend is dat ze goed kunnen vechten, kunnen hun reputatie gebruiken om dingen gedaan te krijgen. De uitgaanswereld biedt vechters naast de wedstrijdring een tweede podium dat geschikt is om een reputatie te vestigen. ${ }^{84}$ 'Je moest eens weten hoe vaak ze mij uitdagen. "Kom dan, kom dan"' (interview respondent C3). Ook Jan Plas laat niet na daar gebruik van te maken. 'Een van de jongens van Mejiro werd geweigerd bij discotheek Toy Shop op de Oudezijds Voorburgwal. Hij vroeg naar de reden, want hij was natuurlijk niet blij. Het gesprek werd onvriendelijk en toen kreeg hij klappen. Hij vertelt dat aan Jan Plas en die gaat naar de discotheek en geeft de beide portiers een pak slaag. "Luister effe. Nou nooit meer jongens van onze sportschool slaan, zodat we niet meer terug hoeven te komen." Zo krijg je een reputatie, zo krijgt de school een reputatie' (interview respondent M2).

Zo'n reputatie kan worden gevestigd door te vechten in het uitgaansleven, maar ook van een kampioen is bekend dat hij een goede vechter is en dat wordt door criminelen op waarde geschat. 'Criminelen stapten op de kampioen af. Als je een goede bekende vechter kon toevoegen aan je groep, vergrootte je je aanzien, reputatie' (interview respondent C3). Het overkomt een kampioen dat hij benaderd wordt door mensen die vriendelijk zijn en hem fêteren omdat ze het belangrijk vinden met hem gezien te worden. Hij geniet van de aandacht en maakt dingen mee die hij zich niet kan veroorloven. Pas in een later stadium kan worden gevraagd om een wederdienst. Thom Harinck kan uitgebreid vertellen over de 'mensen met dure klokkies' die bij tijd en wijle in zijn gym opduiken, maar die niet

82 Gottmers \& Stoorvogel 2010, p. 49.

83 H. ten Voorde \& F. van Gemert, 'Van ingehuurde vuisten tot beroepsgroep. Een etnografisch onderzoek naar portiers in een Nederlandse stad', Tijdschrift voor Criminologie 2008, 4, p. 372-383; Van Gemert 2015, p. 71-100. 
komen om te trainen. Een ervaren trainer herkent de situatie en waarschuwt zijn leerling, maar voor een jonge vechter lijken deze verlokkingen ongevaarlijk. ${ }^{85} \mathrm{Wat}$ volgt kan beginnen met een verzoek om samen ergens heen te gaan, een pakje af te leveren of iets op te halen, iemand aan te manen een belofte na te komen, en verdergaan met een rol als bodyguard of erger.

\section{Slot}

Kickboksen in Nederland raakt in de beginjaren verknoopt met criminaliteit als knokkers van de straat worden getraind door vrije jongens, die naar eigen inzicht nieuwe vechtstijlen ontwikkelen en wedstrijden gaan organiseren. Via de gyms en in de uitgaanswereld komen vechters in aanraking met kringen met criminele activiteiten en in de beginjaren fungeren trainers eerder als schakels dan als obstakels op deze route. Een deel van de vechters gaat mee in wat daar gebeurt, omdat de hiërarchie en strikte discipline van de gym kritiek smoren en de inkomsten en waardering op de rand van de onderwereld een verlokkende werking hebben.

In literatuur over de link tussen criminaliteit en vechtsport ligt de nadruk op leren. Wat wordt er geleerd en wie zijn de voorbeelden? Deze vragen zijn relevant en ze brengen voor de hier besproken vroege episode van het Nederlandse kickboksen de positie en rol van trainers naar voren. Harinck en Plas verkeren niet alleen in dezelfde kickboksomgeving, ze bewegen zich ook in het milieu van penoze op de Amsterdamse Wallen van de jaren zeventig en tachtig. Ook deze specifieke setting is van belang voor beantwoording van de centrale vraag, want de historisch-sociologische context is nodig om het proces van verknoping te kunnen beschrijven.

Kickboksen is in deze periode niet de populaire vechtsport die het nu is, maar een nieuwe stijl die door de goegemeente wordt afgekeurd vanwege het harde fullcontact karakter. Het is precies deze eigenschap die door de Amsterdamse knokkers van de straat en door de penoze juist zeer wordt gewaardeerd. Dit aspect van waardering, dat dus kleeft aan de vroege jaren, draagt bij aan de vorming van een niche rond kickboksen. Een gevolg is dat reguliere sponsoren geen interesse hebben voor de nieuwe vechtsport, zodat er mogelijkheden ontstaan voor bedrijven als The Bulldog, Casa Rosso en Yab Yum, die veel van de vroege gala's steunen. Dit onderstreept het maatschappelijke isolement van kickboksen in de vroege periode en het toont tegelijkertijd de geringe afstand tot de onderwereld. Vechters komen in aanraking met anderen die het niet zo nauw nemen met de letter van de wet. Dat weten ze, maar in de gym wordt zowel de fysieke als de morele afstand tot deze personen met harde trainingsarbeid verkleind en komen juist overeenkomsten naar boven. Er ontstaat een ambigue situatie waarin criminelen geen gevaarlijke vreemden zijn, maar geschikte trainingsmaten met wie een vertrouwensband bestaat. In het uitgaansleven zijn het vriendelijke passanten die 
hun waardering voor vechters laten blijken en hun aanlokkelijke voorstellen kunnen doen.

Jaren achtereen is er nauwelijks bemoeienis van buiten en vrije jongens kunnen hun eigen koers bepalen. Nederlandse kickboksers boeken sportieve successen, maar een doordacht plan voor kickboksen op langere termijn is er niet. Er worden weliswaar bonden opgericht, maar dat zijn er meerdere, want vrije jongens zijn het ook onderling niet snel eens. Met het ontbreken van een overkoepelende structuur is ook de mogelijkheid tot controle gering en dat vergroot de mogelijkheden voor schimmige organisatie van evenementen in de jaren die volgen. Kickboksen is niet een sport naar olympisch model geworden, eerder is het een commerciële onderneming die in het neoliberale tijdvak vooral spectaculaire gevechten op de markt wil brengen. ${ }^{86}$

Wat betekent dit voor de huidige discussie over regulering? Vooral vanwege de toestroom van jeugdige beoefenaars bestaat behoefte aan een verantwoord medisch en pedagogisch klimaat. De knokkers van weleer zijn deels de vrije jongens van nu. Dit zijn niet mensen die zich makkelijk in een keurslijf laten dwingen en er is geen overkoepelende structuur met gezag die hun iets kan opleggen. Verandering wordt als ongemakkelijk of zelfs bedreigend ervaren. De nieuwe Vechtsportautoriteit staat voor een lastige, maar ook een belangrijke taak. 